\title{
GOVERNANCE IN MENTAL HEALTH NURSING
}

\author{
ANDRIA PRAGHOLAPATI \\ Prodi Keperawatan, FPOK, Universitas Pendidikan Indonesia \\ Andria.pragholapati@upi.edu
}

\begin{abstract}
Introduction: Governance is a term that is applied to gather all activities that promote, review, measure and monitor the quality of patient care into an integrated and coherent whole. The aim is to adhere to the concept of governance in psychiatric nursing. This research method uses a literature review searching electronic data base. Conclusion Governance is the primary vehicle used by hospitals to be responsible for protecting high standards of health care (including dealing with poor performance professionals), for continuing to improve the quality of their services, and for creating and maintaining an environment where clinical excellence can flourish. The principles developed by interdisciplinary working groups are reviewed for clarity and usefulness by health managers, clinical directors, senior nurses and midwives, health and social care professionals and patient groups.
\end{abstract}

Keywords: Governance, Psychiatric Nursing

\section{Definition of governance in mental nursing}

Governance is the framework in which the health team is responsible for quality, safety and patient satisfaction in the care they provide. It is built on the model of chief executive officer (CEO) / general manager (GM) or the equivalent of working in partnership with clinical directors, director of nursing / midwifery and professional services / leads. The key characteristics of nursing governance are culture and commitment to the agreed service level and quality of service to be provided.

Governance is a term that is applied to gather all activities that promote, review, measure and monitor the quality of patient care into a coherent whole.

In Western Australia, it has been defined as a systematic and integrated approach to assurance and review of clinical responsibility and accountability that improves quality and safety so that optimal patient outcomes.

Governance is the primary vehicle used by hospitals to be responsible for protecting high standards of health care (including dealing with poor performance professionals), for continuing to improve the quality of their services, and for creating and maintaining an environment where clinical excellence can flourish. 
Structural changes have affected how hospitals regulate, provide and review service standards. Some have led to marked improvement in services, especially where senior doctors have been given responsibility for the delivery of health services and the performance of the clinical directorate. On the other hand, dividing hospitals into directorates has sometimes focused specialists' interests even stronger in their own areas, leading to competition for resources and limiting interactions.

As a result, the opportunity to use lessons from mistakes to benefit other patients, even in the same institution, is sometimes lost. By bringing together all clinical quality activities under one umbrella, clinical governance addresses these obstacles, ensuring quality improvement can benefit all organizations. 4

The introduction of clinical governance is therefore aimed at improving the quality of clinical care at all levels of the organization by consolidating, codifying, and standardizing organizational policies and approaches, especially clinical and accountability. 5 Clinical governance companies have a number of similarities with corporate governance.

"The resonance of the two terms is important, because if clinical governance is to be successful it must be supported by the same strengths as corporate governance: it must be strict in its application, organization-wide in emphasis, accountable in delivery, development driven, and positive in the connotation letter ".6

According to OECD principles of corporate governance, well-managed organizations are those whose financial control, service performance, and clinical quality are fully integrated at every level. In the health sector, this will require every service to work out accountability arrangements in detail and ensure these arrangements are known to all stakeholders in all organizations.7

\section{The purpose of governance in mental nursing}

Where attention focuses less on clinical priorities than on target activities, waiting list initiatives and financial problems, doctors can become frustrated and demoralised

Governance provides high-quality health care regardless of its legal status along with service performance and financial control in each regional health service and the whole health care system as a whole. However, as the possibility of treatment develops, the social setting in which health care is provided is also becoming increasingly complex. 
Health service delivery faces many challenges and changes, including increasing demand for quality health services. Changing work patterns, while bringing important benefits, carries additional responsibilities and risks. Traditionally, junior doctors provided continuity in treating patients at the cost of punishingly long hours and personal sacrifice. Limiting their work hours reduces the risk of errors triggered by fatigue, but heightens the need for good communication between successive shifts.

The largest working group in Western Australia's health system, in 2000, some 25,600 nurses were registered on the Western Australia Nurses Board. These nurses also face new challenges in providing quality health services as their roles now include more demanding scientific monitoring, measuring and recording responsibilities, which has resulted in new barriers between nurses and their patients. 11 As the relationship between nurses and patients changes their focus and intensity The long, fine and smooth daily safety net of conversations, which might have previously been warned by nurses of mistakes or negligence, might be lost.

Nurses now report that they do not feel valued by the system and this in turn has resulted in a decline in the nursing workforce locally12 as well as throughout the world. Hospitals are thus forced to employ more temporary staff, who may not be familiar with ward routines or protocols and who may be directed to different wards on successive shifts.

Patients now spend only their most acute phase of the disease in the hospital. Many different professional groups - and sometimes institutions - can participate in episodes of care, especially when the preentry, sub-acute or rehabilitation phase is considered. As more individuals from groups are more visible after patients in a tight time frame, maintaining consistently high standards of care - even in single health care episodes - becomes more challenging. The potential for error increases, especially every time responsibility is transferred from one institution to the next. Each transfer requires comprehensive, accurate and timely communication, regardless of distance, shifting patterns or competing clinical demands.

Maintenance failures - whether through mistakes, ignorance or neglect - have a great opportunity cost. Individual patients pay with physical and / or psychological discomfort, lost work or school days, and are sometimes restricted or future is reduced. The population pays as health dollars 
diverted from prevention, diagnosis and treatment for insurance premiums and management of adverse outcomes. Health staff pay because they become discouraged and frustrated and lose public trust in the health system.

Operating in complex and demanding environments, the health system must recognize and respond to these clinical and social challenges. At the same time, it must be seen to do what it says it does not. clinical governance offers a way to achieve this.

Being attacked almost every day by media reports seems to be limited medical discoveries and advances, so this public health service expectations have never been higher.

At the same time, a series of medical disasters has received wide coverage. In the United Kingdom, Bristol Cardiothoracic demand to a very high level of perinatal mortality 13 receives regular media attention over the age of three years. During the same period, British GP Harold Shipman was convicted of killing at least 15 middle-aged and elderly female patients.

In the US, a high-profile health reporter for the Boston Newspaper Globe died after a major chemotherapy overdose at age 39, while he was being treated for breast cancer in a highly respected specialist cancer institution. A similar overdose was given to other patients at the institution the previous month. although hospitals respond in the traditional way by disciplining 16 nurses, the media takes perhaps a more considered view. The Globe itself said the action was "misguided because it focused on individuals despite errors caused by failures in the design of treatment systems."

In Western Australia, the Douglas Inquiry14, whose clinical practice and management was investigated at Edward's King Memorial Hospital between 1990-2000, has received much national attention, especially with respect to the findings of the investigation of poor policies and inadequate practices and systems that result in poor outcomes for patients and their family.

However, examples of individuals like this seem to symbolize the concerns of the entire system. Research papers published in Australia, New Zealand, the United Kingdom and the United States have all reported previously unknown levels of iatrogenic injury to patients.

As long ago as 1974, California hospital records15, and New York State hospital results ten years later16, showed a sudden high rate of side effects. In the New York study of 51 acute care, non-psychiatric hospitals, $3.7 \%$ of the more than 30,000 
episodes of hospitalization included dangerous side effects, and in $0.7 \%$, patients suffered permanent disability or died. Good research, however, is causing every major change in hospital practice.

The next major report came from Australia at 199,517, and this shows $16.6 \%$ of admissions to Australian hospitals during 1992 were associated with iatrogenic injuries and deaths resulted in nearly $5 \%$ of these cases. Importantly, a panel of specialists reviewing this case felt half of the potentially preventable side effects. the authors conclude the emphasis must be on designing safer systems to protect patients from "inevitable human error" 18. Making systems safer, and aligning management priorities with those of doctors, is the solution, they say.

The other two, more limited, reports - one from UK19 and the other from New Zealand20 found the same level of side effects (10.7\% and $10 \%$ respectively) and potential for prevention (46\% and 40\%).

The New Zealand error caused an additional 6.7 health days per incident, while extrapolating British results, the mistake could explain spending of $£ 1$ billion a year21.

In the United States, a Juran Institute study found $30 \%$ of all direct health spending was the result of poor quality care - especially because it was overused (including investigations and some drugs), abuse (such as drug or equipment abuse) and waste (especially administrative activities necessary) 22. As lead author on Quality in Australia Health Report to Norman Swan on $\mathrm{ABC}$ radio,

"There is no question like that in industrial manufacturing, it's cheaper to do it right the first time." 23

The aim in reducing clinical errors triggered a major report by the US Institute of Medicine's National Academy of Science, For Err's Humans: Building a Safe Health System24, which suggested 48,000 98,000 American in-patients die due to iatrogenic errors each year. In this report, patient stories are commonly given names, and if statistics are densely accessed by comparison with deaths from driving drunk and breast cancer.

This time, media attention ensured a quick response from both the President and Congress in America and even spawned a four-part television documentary film in the UK, Why Doctors Make Mistakes25. Patient safety also makes the front page of Canadian Maclean's news magazine26

A public poll with the Kaiser-Harvard Health News Index four weeks later showed 
more than half of those interviewed knew about the Institute of Medical findings

\section{The principles of governance of Mental}

\section{health nursing}

To help health care providers a suite of ten principles of good clinical governance, in the Irish health context, has been developed with titles and descriptions. The principles developed by interdisciplinary working groups are reviewed for clarity and usefulness by managers. 


\section{REFERENCES}

[1] Pragholapati and F. Munawaroh, "Resiliensi pada lansia," J. Surya Muda, vol. 2, no. 1, pp. 1-8, 2020.

[2] Pragholapati, F. Munawaroh, Stik. Jenderal Achmad Yani, and Stik.Bhakti Kencana Bandung, "RESILIENSI PADA LANSIA,” ejurnal.ars.ac.id, vol. 2, no. 1, p. 2020.

[3] Pragholapati, "RESILIENSI PADA KONDISI WABAH COVID-19,” 2020.

[4] Pragholapati, F. Munawaroh, Stik. Jenderal Achmad Yani, and Stik.Bhakti Kencana Bandung, "RESILIENSI PADA LANSIA," ojs.stikesmuhkendal.ac.id, vol. 2, no. 1, p. 2020.

[5] Pragholapati, "Hubungan masalah kesehatan jiwa dengan strategikoping seseorang yang mengalami perceraian di kota bandung," 2016.

[6] Pragholapati and W. Ulfitri, "Gambaran Mekanisme Coping padaMahasiswa Program Studi Sarjana Keperawatan Tingkat IV yang SedangMenghadapi Tugas Akhir di Sekolah Tinggi Ilmu Kesehatan X Bandung,” Humanit. (Jurnal Psikologi), vol. 3, no. 2, pp. 115$126,2019$.

[7] Pragholapati, R. S. Oktapiani, and Efri Widianti, "Pengaruh Brain GymTerhadap Tingkat Depresi Pada Lansia Di Balai Perlindungan SosialTresna Werdha Ciparay Bandung," Sk. keperawatan, vol. 5, no. 2, pp. 128-146, 2019.

[8] Pragholapati, U. Padjadaran, and F. Keperawatan, "PERAWAT YANG BEKERJA DI UNIT GAWAT DARURAT ( UGD ) RUMAH SAKIT AL ISLAM ( RSAI ) BANDUNG THE CORRELATION OF RESILIENCY WITH NURSE' S WORK STRESS IN EMERGENCY UNIT RUMAH SAKIT AL ISLAM ( RSAI ) BANDUNG,” 2010.

[9] Ariani et al., "INFORMATION COMMUNICATION TECHNOLOGY ( ICT ) IN MIDWIFERY EDUCATION (A REVIEW OF THE LITERATURE ),” vol. 3, no. 1, pp. 2014-2017, 2019.

[10] Pragholapati, “COVID-19 IMPACT ON STUDENTS,” pp. 1-6, 2020.

[11] Pragholapati, "Self-Efficacy Of Nurses During The Pandemic Covid19," no. May 2020, p. 2020.

[12] Pragholapati, "HUBUNGAN BULLYING DENGAN KEMAMPUAN SOSIAL PADA REMAJA DI SMK X KOTA BANDUNG,” vol. 9, no. 1, pp. 34-40, 2020.

[13] Pragholapati, A. (2020). Anxiety in Someone Who Has Divorce. 
[14] Pragholapati, A. (2020). STRES KERJA PERAWAT YANG BEKERJA DI UNIT GAWAT DARURAT (UGD) RUMAH SAKIT AL ISLAM (RSAI) BANDUNG.

[15] Pragholapati, A. (2020). RESILIENSI PERAWAT YANG BEKERJA DI UNIT GAWAT DARURAT (UGD) RUMAH SAKIT AL ISLAM (RSAI) BANDUNG.

[16] Pragholapati, A. (2020). Depression in Someone Who Has Divorce.

[17] Pragholapati, A. (2020). DEVELOPMENT OF CURRICULUM OF HIGHER EDUCATION (3 COUNTRIES).

[18] Pragholapati, A. (2020). The Role of Nurses in Divorce.

[19] Pragholapati, A. (2020). Depression in Someone Who Has Divorce. 